\title{
Effect of duck genotype on leg muscle properties
}

\author{
Janina Wołoszyn', Andrzej Okruszek', Agnieszka Orkusz', Monika Wereńska', Juliusz
} Książkiewicz ${ }^{2}$ and Halina Grajeta ${ }^{3}$

'Wrocław University of Economics, Department of Animal Food Technology, Wrocław, Poland, ${ }^{2}$ National Research Institute of Animal Production, Department of Animal Genetic Resources Conservation, Balice, Poland, ${ }^{3}$ Wrocław Medical University, Department of Food Science and Dietetics, Wrocław, Poland

\begin{abstract}
The research objective was to compare the nutritive value and some functional properties of duck leg muscles from different flocks. A total of 80 drakes out of three conservative flocks (cross-breeds Pekin type - SB, Miniduck - K2, Pekin originated from Danish Pekin duck - P8) and one maternal breeding strain (P66) aged seven weeks, were used for comparison. The content of protein, lipids, moisture, essential amino acids, fatty acids and cholesterol were estimated. The investigation of functional properties has covered: the determination of the colour parameters $-L^{*}, a^{*} b^{*}$, colour difference between individual flocks, total haem pigments' content, sensory evaluation of raw muscles' colour intensity in 10 point scale; $\mathrm{pH}_{24}$; water holding capacity; cooking loss and shear force. Comparing the basic chemical and amino acid composition, cholesterol content and profile of fatty acids, it could be concluded that the P66 leg muscles coming from a selected breeding strain, are the most favourable from the nutritional point of view. It is evident too, that muscles from all the examined flocks have been characterized by a high nutritional value. Taking into consideration the functional properties, it was concluded that the muscles from the investigated flocks varied in colour and analysed traits. The ducks of K2 had the best functional properties. The advantages of K2 in comparison to the other ducks are: darker colour typical of waterfowl meat, lower cooking loss, higher water holding capacity and lower shear force.
\end{abstract}

Keywords: duck, leg muscle, chemical composition, functional properties

\section{Zusammenfassung}

\section{Auswirkungen des Entengenotyps auf die Beinmuskeleigenschaften}

Ziel der Untersuchung war es, den Nährwert und einige funktionelle Eigenschaften des Beinmuskels von verschiedenen Entenherden zu vergleichen. Bei insgesamt 80 Erpeln im Alter von 7 Wochen aus drei Erhaltungszuchten (Kreuzungen aus Pekingtyp [SB], Miniente [K2] und Pekingente dänischer Herkunft [P8]) und einem Mutterzuchtstamm (P66) wurden der Gehalt an Eiweiß, Lipiden, Trockensubstanz, essentiellen Aminosäuren und Cholesterin bestimmt. Bei den funktionellen Eigenschaften wurden untersucht: Farbparamenter $L^{*}, a^{*}$, $b^{*}$, Farbunterschiede zwischen den Herden, Gesamthaempigment, sensorische Bewertung der Farbintensität von Muskeln mittels 10-Punkte-Skala, $\mathrm{pH}_{24^{\prime}}$ Wasserhaltevermögen, 
Kochverluste und Scherkraft. Der Vergleich von chemischer Zusammensetzung und Art und Anteil der Aminosäuren und des Cholesterins ergab, dass der Beinmuskel des P66Stamms für die Ernährung am geeignetesten ist. Ebenfalls steht fest, dass die Muskeln aller untersuchter Herden einen hohen Ernährungswert aufweisen. Bei den funktionellen Eigenschaften wurde festgestellt, dass sich die Muskeln der beobachteten Herden farblich und hinsichtlich der untersuchten Eigenschaften unterschieden. Im Vergleich besaßen die K2-Enten besten funktionellen Eigenschaften: die für Wasservögel typische dunklere Farbe, geringere Kochverluste, höheres Wssserhaltevermögen und kleinere Scherkräfte.

Schlüsselwörter: Ente, Beinmuskel, chemische Zusammensetzung, funktionelle Eigenschaften

\section{Introduction}

Although waterfowl is a popular source of meat and makes a significant segment of the agricultural economy in many countries, it makes up only a small proportion of the total poultry meat industry. For the duck production the main problem are the costs. The meat yield of ducks has therefore increased and carcass fattiness has decreased owing to the genetic selection and improvements in bird management. At the same time, the interest in the nutritive value, technological and sensory quality of duck meat has increased. The main species used to produce duck meat are Pekin, Muscovy (mostly in France) and mule ducks (mostly in France for the production of fatty liver, and Taiwan). Other species such as Jinding and Shao ducks in China, Tsaiya ducks in Taiwan, Khaki Campbell, Indian runner and Desi ducks in India, Vietnam, Cambodia and Indonesia are used mainly for egg production and meat is only a by-product (Baéza 2005).

There are many different duck genotypes, and as in other countries in Poland is carried out a breeding program for the preservation of duck genetic resources. These, conservative flocks were used in the development of new breeding and experimental strains and synthetic lines as well as in the search for heterosis effects in commercial sets. Genetic reserve flocks include among others: cross-breeds Pekin type - SB, Miniduck - K2, Pekin originated from Danish Pekin duck - P8, belonging to the conservative flocks, Pekin type breeding strain P66. The unique on international scale populations of birds are kept by in situ method at the Waterfowl Genetic Resources Station of the National Research Institute of Animal Production in Dworzyska, Poland. The birds are characterized by very good health, resistance to variable, often adverse climatic conditions of the region of their origin and good conversion of farmproduced feeds (Mazanowski 2002, Książkiewicz 2002, 2003, 2007).

The previous studies about characteristic of conservative duck flocks concerned mainly carcass traits (such as: body weight, percentage yield of muscles, skin with subcutaneous fat and abdominal fat) and nutritive value of breast muscles of only some flocks (Książkiewicz 2003, Kisiel \& Książkiewicz 2004, Wołoszyn et al. 2006, 2007, 2009, Haraf et al. 2009). The percentage yield of leg muscles in the duck carcass is about $20 \%$ in relation to age, breed and sex of the birds. However data on the nutritive value and functional traits of leg meat of the specific ducks are scarce and this was the reason for undertaking the investigation on this subject. 
The aim of this paper was to characterize and compare the nutritive value (proportion of protein, fat, moisture, cholesterol, amino acid, fatty acid composition), colour (by determining $\mathrm{L}^{*}, \mathrm{a}^{*}, \mathrm{~b}^{*}$ parameters, colour difference $\Delta \mathrm{E}$ between individual flocks), sensory evaluation (SE) of meat colour intensity, total haeme pigment (THP) content), $\mathrm{pH}_{24}$, water holding capacity (WHC), cooking loss (CL) and shear force (SF) of ducks' leg muscles from different flocks.

\section{Materials and methods}

The experiment involved ducks from three conservative flocks and one selected breeding strain maintained by in situ method in the Waterfowl Genetic Resource Station in Dworzyska near Poznań. The characteristic of the ducks was given in Table 1.

Table 1

Genotypes used for investigation

\begin{tabular}{|c|c|c|}
\hline Flock & Origin of ducks & Short characteristic \\
\hline P8 & $\begin{array}{l}\text { Pekins of Danish origin - } \\
\text { progeny of Pekin parents imported } \\
\text { from Denmark in } 1978 \text { (conservative).* }\end{array}$ & $\begin{array}{l}\text { They are characterized by white plumage. } \\
\text { Legs and beak are yellow and orange. } \\
\text { Weight of adult birds range from } 3200 \text { to } 3400 \mathrm{~g} \text {. } \\
\text { These ducks are characterized by outstanding } \\
\text { reproduction and meatiness traits. }\end{array}$ \\
\hline SB & $\begin{array}{l}\text { Cross - breeds of ducks from three } \\
\text { conservative groups A1, A2 and A3, } \\
\text { which were progeny of Pekin ducks } \\
\text { imported from England in } 1977 \\
\text { (conservative).* }\end{array}$ & $\begin{array}{l}\text { Feathers of these ducks are white, legs are orange and } \\
\text { yellow, beak is yellow or pale pink. Adult birds weigh } \\
\text { from } 2900 \mathrm{~g} \text { to } 3100 \mathrm{~g} \text {. The birds are characterized by } \\
\text { very good musculature. }\end{array}$ \\
\hline $\mathrm{K} 2$ & $\begin{array}{l}\text { Miniduck - crossbred of wild white } \\
\text { mallards (Anas platyrhynchos } L .) \text { and } \\
\text { light Pekin type ducks (conservative).* }\end{array}$ & $\begin{array}{l}\text { It has white plumage with no special feather pattern, } \\
\text { white skin, yellow shanks and feet. It is a medium-sized } \\
\text { duck with an adult male weighing } 1700 \text { and a female } \\
1600 \mathrm{~g} \text { on average. The birds are characterized by very } \\
\text { well developed muscles and low fatness. }\end{array}$ \\
\hline P66 & $\begin{array}{l}\text { Maternal strain, selected meat type, } \\
\text { bred from Pekins originating from } \\
\text { Poland.** }\end{array}$ & $\begin{array}{l}\text { It has the white colour plumage, dark yellow shanks and } \\
\text { feet and long orange beak. The adult birds reach about } \\
2600 \mathrm{~g} \text { body weight. The A } 55 \text { male and P } 66 \text { female } \\
\text { ducks have been the parental combination for broiler } \\
\text { production. The parental combinations of those strains } \\
\text { for production of two strain crosses have been } \\
\text { characterized by very good musculature and low fatness. }\end{array}$ \\
\hline
\end{tabular}

*Książkiewicz 2002, ${ }^{* *}$ Mazanowski 2002

During the testing period ducks were reared up to the 4th week of age in a poultry house of controlled air temperature, and afterwards they were kept on yards of restricted area, partially shaded and covered with straw. All birds were fed ad libitum on the same complete feeds (Table 2).

In the 7th week of age, from each flock (comprising 60 birds) 10 males were taken for analysis (two experiments were made $-2 \times 10$ birds per genotype) having body weight close to the arithmetic mean of body weight in a particular flock (Table 3 ). 
Table 2

Diet composition used in the trial

\begin{tabular}{lcc}
\hline Ingredients, \% & $1-21$ days & $22-49$ days \\
\hline Wheat meal & 72.8 & 57.6 \\
Soybean meal & 17.0 & 10.0 \\
Barley meal & 17.4 & - \\
Rapeseed oil & 1.0 & 1.6 \\
Fish meal & 5.4 & 4.0 \\
Premix KB, vitamin-mineral premix & 1.0 & 1.4 \\
Chemical composition, \%/kg of diet & & \\
Crude protein & 20.0 & 16.5 \\
Ether extract & 4.00 & 3.00 \\
Ash & 5.50 & 6.00 \\
Cellulose & 3.50 & 5.00 \\
L-Lysine & 1.05 & 0.820 \\
D-L Methionine & 0.490 & 0.460 \\
Calcium & 0.850 & 0.860 \\
Total phosphorus & 0.700 & 0.800 \\
Vit. A, IU/kg & 15000 & 14000 \\
Vit. D IU/kg & 3500 & 2000 \\
Vit. E, mg/kg & 60 & 50 \\
Metabolizable energy (ME), MJ/kga & 12.1 & 12.3 \\
\hline
\end{tabular}

aThe caloric value of all-mashes calculated on basis of percentage content of some analytic components of feed, expressed in a megajoule (MJ) metabolizable energy (ME) per $1.0 \mathrm{~kg}$ of fed mixture, with a level nitrogen adjusted in following method (Ministry of Agriculture and Rural Development, [2009]): MJ $/ \mathrm{kg} \mathrm{ME}=0.1551 \times \%$ crude protein + $0.3431 \times \%$ crude fat $+0.1669 \times \%$ starch $+0.1301 \times \%$ total sugar content (expressed as sucrose) .

Table 3

Experimental design

\begin{tabular}{lrrrr}
\hline Specification & P66 & K2 & SB & P8 \\
\hline Number of male birds & 60 & 60 & 60 & 60 \\
Slaughtered, $n$ & 20 & 20 & 20 & 20 \\
Age at slaughter, weeks & 7 & 7 & 7 & 7 \\
Mean weight at slaughter, g & 2583 & 1577 & 2498 & 2675 \\
\hline
\end{tabular}

The slaughter of birds and cutting out of all leg muscles (thigh and drumstick with intramuscular fat and without skin and subcutaneous fat) were done in a local slaughterhouse, according to the referent regulations applied in the poultry industry. The leg muscles were stored at $2-4^{\circ} \mathrm{C}$ for $24 \mathrm{~h}$ after slaughter and then investigated.

Chemical analyses in homogenates were carried out using the following methods:

- Moisture, protein, and lipids - were determined with standard methods (AOAC 1990).

- Cholesterol - using the enzymatic Human test in an extract prepared by Folch et al. (1957) procedure. The saponification was carried out by Rhee et al. (1982) method.

- Amino acid composition - was determined using HPLC Agilent Tech. 1200 Chromatograph (Agilent Technologies, Inc., Santa Clara, CA, USA) with a fused silica capillary column Zorbax Eclipse-AAA column - 3.0 $\times 150 \mathrm{~mm} \times 3.5 \mu \mathrm{m}$ and diode-array detector (DAD) according to the manufacturer's recommendations. The hydrolysis of meat samples and the analysis were performed following the procedures described by Wołoszyn et al. (2006). Coefficients of essential amino acids ( $\mathrm{R} \%$ ) were established according to the formula: 
$R(\%)=100 \% \times A_{m} / A_{s^{\prime}}\left(A_{m}\right.$ : essential amino acid content in the duck meat protein; $A_{s}$ : essential amino acid content in the standard FAO/WHO/UNU [2007]).

- The composition of fatty acids was determined using the gas chromatography technique with the Agilent 6890N Gas Chromatograph (Agilent Technologies, Inc., Santa Clara, CA, USA), equipped with a flame-ionization detector. The methyl esters of fatty acids were separated on the fused silica CP-Sil 88 (ChromPack, Middelburg, The Netherlands) capillary column $(100 \times 0.25 \mathrm{~mm})$, helium was used as the carrier gas. The separation was conducted at the programmed temperature from 165 to $220^{\circ} \mathrm{C}$ by an increase rate at $2^{\circ} \mathrm{C} / \mathrm{min}$. The identification of fatty acids was accomplished by comparison with external standards. The fatty acids were calculated as $\%$ of total fatty acids with the Agilent ChemStation v. B.04.02. SP1 (Agilent Technologies, Inc., Santa Clara, CA, USA) programme.

Functional properties were carried out using the following methods:

- The colour parameters in the middle part of the inner side of leg muscles are presented in the $L^{*}, a^{*}, b^{*}$ colour scale (Cie 1986) using an automated Minolta Chroma Meter CR-310 (Minolta Camera Co. Ltd, 2-Chome, Osaka, Japan) with light source D65 and $8 \mathrm{~mm}$ measuring cell. $L^{*}$ is a measure of lightness: 0 equals black - 100 equals white. High positive values of $a^{*}$ indicate redness and large, negative values indicate greenness. High positive $b^{*}$ values indicate yellowness and large, negative values indicate blueness. Before measurements the apparatus was calibrated according to the white reference standard: $Y=94.2 ; \mathrm{x}=0.313$; $y=0.324$ (CIE 1986). The colour difference $(\Delta \mathrm{E})$ was calculated from the formula: $\Delta \mathrm{E}=\left[\left(\Delta \mathrm{L}^{*}\right)^{2}+\right.$ $\left.\left(\Delta a^{*}\right)^{2}+\left(\Delta b^{*}\right)^{2}\right]^{1 / 2}$. The $\Delta L^{*}, \Delta a^{*}$ and $\Delta b^{*}$ were differences between mean $L^{*}, a^{*}$ and $b^{*}$ values for individual flocks.

- Sensory evaluation (SE) of the raw muscles' colour was conducted by the sensory panel (7 trained people) according to Analsens NT programme (Baryłko 2000) using 10 point scale (1 - very light colour; 10 - very dark colour) of intensity and expressed in conventional units (CU) (Baryłko-Pikielna \& Matuszewska 2009).

- The total heam pigments (THP) content was determined in accordance with the Warriss procedure described by Haraf et al. (2009).

- The measurements of pH were done using a digital Metrohm pH-meter 654 series (Metrohm Ltd. CH-9100 Harisau, Switzerland), equipped with a combination type of $\mathrm{pH}$ spearhead electrode Double Pore Slim (Hamilton Company, Reno, NV, USA) and a thermometer.

- Water holding capacity (WHC) - was determined using a filter paper press method (Grau \& Hamm 1957). The minced meat $(300 \mathrm{mg})$ was placed on the Whatman filter paper and next put between two glass plates and exposed to $1 \mathrm{~kg}$ pressure for $1 \mathrm{~h}$. The WHC was expressed as: $100 \% \times M / T$, where $M$ is the area $\left(\mathrm{cm}^{2}\right)$ of the meat and $T$ is the total area $\left(\mathrm{cm}^{2}\right)$.

- Cooking loss (CL) - was determined with the Kotter et al. (1968) method. The minced meat samples weighing $30 \mathrm{~g}$ were placed into a strainer and put to the thermostat at $80^{\circ} \mathrm{C}$ for 20 min. Next samples were taken immediately, gently blotted dry and next weighed. Cooking loss was expressed as a percentage of the initial weight.

- Shear force (SF) of muscles was carried out using an Instron Universal Testing Machine Model 5543 (Instron, Norwood, MA, USA). The four $12.7 \mathrm{~mm}$ diameter round cores (length $=10 \mathrm{~mm}$ ) were obtained from each muscle. The cores were collected parallel to the muscle fibres, using a hand-hold steel cork borer. The cores were sheared perpendicular to the fibres with a Warner-Bratzler compression - type shear attachment (1 kN load cell, $200 \mathrm{~mm} / \mathrm{min}$ crosshead speed). 
Statistical analysis was based on arithmetic means ( $\overline{\mathrm{X}}$ ) and standard error (SEM). The effect of flock was analysed by one way analysis of variance (ANOVA) in an orthogonal scheme. The significance of differences between the mean values of investigated traits were determined by Duncan's multiple range test with StatSoft 6.0 (StatSoft, Inc. Tulsa, OK, USA).

\section{Results}

It was found out that the basic chemical composition of the duck leg muscles depended on the genotype of flock. The significant differences in the lipids and cholesterol content were stated. The K2 leg muscles comprised less $(P \leq 0.05)$ lipids than the P66, SB, P8 ones. However the P66 (breeding strain) demonstrated the lowest amounts of cholesterol $(P \leq 0.01)$ in comparison to P8, SB and K2 muscles. There were no significant differences in protein and moisture content (Table 4).

Table 4

Chemical composition and essential amino acids (\% of total protein) composition of leg muscles

\begin{tabular}{|c|c|c|c|c|c|c|}
\hline \multirow[t]{2}{*}{ Parameter } & \multirow[b]{2}{*}{ P66 } & \multicolumn{3}{|c|}{ Flock } & \multirow[t]{2}{*}{ SEM } & \multirow[t]{2}{*}{ Effect of flock } \\
\hline & & $\mathrm{K} 2$ & SB & P8 & & \\
\hline Protein, \% & $20.66^{a}$ & 20.57 & $20.44^{b}$ & 20.56 & 0.68 & ns \\
\hline Lipids, \% & $1.83^{\mathrm{Aa}}$ & $1.47^{\mathrm{B}}$ & $1.79^{A}$ & $1.69^{b}$ & 0.08 & * \\
\hline Moisture, $\%$ & $76.47^{b}$ & $76.55^{b}$ & $76.52^{\mathrm{b}}$ & $76.83^{a}$ & 0.25 & ns \\
\hline Cholesterol, mg/100g & $85.17^{B}$ & $106.31^{\mathrm{AD}}$ & $111.72^{\mathrm{ACb}}$ & $112.85^{\text {ACa }}$ & 0.81 & ** \\
\hline $\mathrm{PHE}+\mathrm{TYR}$ & $7.99^{A}$ & $6.37^{\mathrm{Ba}}$ & $6.25^{\mathrm{Bb}}$ & $6.22^{\mathrm{Bb}}$ & 0.12 & * \\
\hline ILE & $5.67^{A}$ & $3.28^{\mathrm{Bb}}$ & $3.46^{\mathrm{Ba}}$ & $3.35^{\mathrm{B}}$ & 0.08 & * \\
\hline LEU & $8.61^{A}$ & $7.78^{\mathrm{Ba}}$ & $7.67^{B}$ & $7.52^{\mathrm{Bb}}$ & 0.10 & * \\
\hline LYS & $9.59^{a}$ & $9.07^{b}$ & $9.09^{b}$ & $9.11^{\mathrm{b}}$ & 0.09 & ns \\
\hline $\mathrm{MET}+\mathrm{CYS}$ & $3.31^{b}$ & $3.45^{\mathrm{b}}$ & $3.88^{\mathrm{ac}}$ & $3.66^{\mathrm{ad}}$ & 0.21 & ns \\
\hline THR & $5.37^{\mathrm{A}}$ & $4.23^{\mathrm{Bb}}$ & $4.49^{\mathrm{Ba}}$ & $4.37^{\mathrm{B}}$ & 0.11 & ns \\
\hline TRP & $0.77^{\mathrm{B}}$ & $1.19^{\mathrm{Aa}}$ & $0.98^{\mathrm{Bb}}$ & $0.99^{\mathrm{Bb}}$ & 0.02 & * \\
\hline VAL & $6.47^{A}$ & $3.61^{\mathrm{Bb}}$ & $3.67^{B}$ & $3.77^{\mathrm{Ba}}$ & 0.29 & $* *$ \\
\hline
\end{tabular}

The data are average values of 6 tests: $\bar{X} \pm S E M, A, B, C, D$ Values with different letters at the same line are significantly different at $P \leq 0.01, \quad a, b, c, d$ Values with different letters at the same line are significantly different at $P \leq 0.05$; ns $=$ not significant, ${ }^{*} P \leq 0.05,{ }^{*} P \leq 0.01$

The data given in Table 4 show that the leg muscles of investigated ducks contained all essential amino acids like other kinds of meat. The amino acid proportion of meat proteins depended on ducks' flocks, and significant differences were found. The leg muscles from P66 breeding strain comprised more PHE+TYR, ILE, LEU, THR, VAL, and less TRP as compared to muscles of $\mathrm{P} 8, \mathrm{~K} 2$ and $\mathrm{SB}$ conservative flocks. The proteins of $\mathrm{K} 2$ were characterized by the highest content of TRP and lowest of THR in comparison with the muscles of the other ducks. According to the FAO/WHO/UNU (2007) standard, the VAL was amino acid limiting the biological value of meat proteins of K2, SB and P8 (Table 5). Except of VAL, the meat proteins of the investigated raw materials contained more essential amino acids than the standard. The MET+CYS (206.9-242.5) and LYS (201.6-213.1) were characterized by the higher value of index $R$ and thereby possessed the highest biological value among essential amino acids. The leg muscles of P66 contained more of all essential amino acids than the standard, and taking into consideration the biological value of proteins, they appeared to be the most favourable. 
Table 5

Coefficients of essential amino acids (R\%)

\begin{tabular}{llccc}
\hline Amino acid & P66 & K2 & SB & P8 \\
\hline PHE+TYR & 210.3 & 167.6 & 164.5 & 163.7 \\
ILE & 189.00 & 109.3 & 115.3 & 111.7 \\
LEU & 162.4 & 146.8 & 144.7 & 141.9 \\
LYS & 213.1 & 201.6 & 202.0 & 202.4 \\
MET+CYS & 206.9 & 215.6 & 242.5 & 227.5 \\
THR & 233.5 & 183.9 & 195.2 & 190.0 \\
TRP & 128.3 & 198.3 & 163.3 & 165.0 \\
VAL & 165.9 & 92.6 & 94.1 & 96.7 \\
\hline
\end{tabular}

The genotype of ducks affected the profile of fatty acids (Table 6). The unsaturated fatty acids (UFA) were predominant (60.14-64.04\%) in fatty acids composition of intramuscular fat for all flocks. The lipids of P66 breeding strain comprised the most of UFA especially monounsaturated fatty acids (MUFA) and n-3 polyunsaturated fatty acids ( $n-3$ PUFA).

Table 6

Fatty acids in leg muscles

\begin{tabular}{lcccccc}
\hline Parameter & P66 & K2 & $\begin{array}{c}\text { Flock } \\
\text { SB }\end{array}$ & P8 & SEM & $\begin{array}{c}\text { Effect } \\
\text { of flock }\end{array}$ \\
\hline SFA, \% & $30.57^{\mathrm{B}}$ & $32.84^{\mathrm{ACb}}$ & $31.55^{\mathrm{AD}}$ & $33.17^{\mathrm{ACa}}$ & 0.98 & $\mathrm{~ns}$ \\
MUFA, \% & $38.97^{\mathrm{AC}}$ & $30.01^{\mathrm{B}}$ & $36.88^{\mathrm{AD}}$ & $32.96^{\mathrm{BC}}$ & 0.87 & $* *$ \\
PUFA, \% & $25.07^{\mathrm{B}}$ & $30.13^{\mathrm{AC}}$ & $25.12^{\mathrm{B}}$ & $27.93^{\mathrm{AD}}$ & 0.39 & $*$ \\
UFA, \% & $64.04^{\mathrm{AC}}$ & $60.14^{\mathrm{Bb}}$ & $62.00^{\mathrm{AD}}$ & $60.89^{\mathrm{Ba}}$ & 0.81 & $*$ \\
n-6 PUFA, \% & $24.16^{\mathrm{Ab}}$ & $24.85^{\mathrm{ACa}}$ & $23.85^{\mathrm{AD}}$ & $21.33^{\mathrm{B}}$ & 0.63 & $\mathrm{~ns}$ \\
n-3 PUFA, \% & $6.02^{\mathrm{Aa}}$ & $4.25^{\mathrm{B}}$ & $5.69^{\mathrm{Bb}}$ & $5.52^{\mathrm{Bb}}$ & 0.15 & $*$ \\
UFA/SFA & $2.09^{\mathrm{Aa}}$ & $1.83^{\mathrm{b}}$ & $1.98^{\mathrm{b}}$ & $1.73^{\mathrm{B}}$ & 0.19 & $\mathrm{~ns}$ \\
PUFA/SFA & 0.82 & 0.91 & 0.81 & 0.85 & 0.07 & $*$ \\
n-6/n-3 & $4.01^{\mathrm{B}}$ & $5.84^{\mathrm{A}}$ & $4.17^{\mathrm{Ba}}$ & $3.86^{\mathrm{Bb}}$ & 0.28 & $*$ \\
\hline
\end{tabular}

The data are average values of 6 tests: $\bar{x} \pm S E M, \quad A, B, C, D$ Values with different letters at the same line are significantly different at $P \leq 0.01, \quad a, b, c, d V a l u e s$ with different letters at the same line are significantly different at $P \leq 0.05$, ns: not significant, ${ }^{*} P \leq 0.05,{ }^{*} P \leq 0.01$

This is very important because preference in human diets is given to the high level of the n-3 PUFA, which is the most valuable fatty acid in the UFA group from the nutritional and physiological points of view. The muscles of P66 contained less saturated fatty acids (SFA) compared to the conservative flocks, too. The highest content of PUFA was detected in fat of K2 muscles (30.13\%). The UFA:SFA ratio was more favourable (1.98-2.09) for P66 and SB than for the K2 and P8 muscles. The PUFA:SFA ratios ranged to 0.81-0.91 and were on the higher level for all muscles than recommended (0.4). The n-6:n-3 PUFA ratios were 3.86-5.84 and they were close to recommended (4-5). The lipids from leg muscles of P66 selected breeding strain were characterized by the most favourable fatty acid profile among the investigated birds.

The functional properties of the leg muscles were presented in Table 7. Comparing the colour parameters, significant differences were found. The origin of ducks influenced the $L^{*}(P \leq 0.01)$ and $b^{*}(P \leq 0.5)$ values. The $K 2$ muscles were significantly lower in $L^{*}$ and $b^{*}$ and 
higher in $\mathrm{a}^{*}$ values than SB, P8 and P66 ones (Table 7). The highest values in $\mathrm{L}^{*}$ and intensity of yellowness were observed for the SB muscles. There were no significant differences in $L^{*}$, $\mathrm{a}^{*}$ and $\mathrm{b}^{*}$ parameters for $\mathrm{P} 66$ and $\mathrm{P} 8$ muscles. The $\Delta \mathrm{E}$ values (Table 8 ) indicate that pairs of P8, P66 $(\Delta \mathrm{E}=0.25)$ and $\mathrm{P} 8, \mathrm{SB}(\Delta \mathrm{E}=1.45)$ were the most similar as regards colour parameters. The K2 muscles were the most distinct from the P8, P66 and SB flocks ( $\Delta E=5.33-6.09)$. The results obtained in our experiments indicate the large total colour variation of the samples taken from different breeds.

Table 7

Functional properties of leg muscles

\begin{tabular}{lcccccc}
\hline Parameter & P66 & K2 & $\begin{array}{c}\text { Flock } \\
\text { SB }\end{array}$ & P8 & SEM & $\begin{array}{c}\text { Effect } \\
\text { of flock }\end{array}$ \\
\hline $\mathrm{L}^{*}$ & $45.62^{\mathrm{BC}}$ & $41.51^{\mathrm{BD}}$ & $47.63^{\mathrm{A}}$ & $45.81^{\mathrm{BC}}$ & 0.38 & $* *$ \\
$\mathrm{a}^{*}$ & $16.03^{\mathrm{Ba}}$ & $18.70^{\mathrm{A}}$ & $15.72^{\mathrm{Bb}}$ & $16.11^{\mathrm{Ba}}$ & 0.20 & $\mathrm{~ns}$ \\
$\mathrm{~b}^{*}$ & $5.42^{\mathrm{B}}$ & $3.31^{\mathrm{B}}$ & $6.82^{\mathrm{AC}}$ & $5.54^{\mathrm{AD}}$ & 0.13 & $*$ \\
$\mathrm{THP}, \mathrm{mg} / \mathrm{g}$ & $2.89^{\mathrm{Ba}}$ & $3.96^{\mathrm{A}}$ & $2.55^{\mathrm{Bb}}$ & $2.75^{\mathrm{B}}$ & 0.11 & $*$ \\
$\mathrm{SE}(\mathrm{CU})$ & $6.53^{\mathrm{Ba}}$ & $7.50^{\mathrm{A}}$ & $6.16^{\mathrm{Bb}}$ & $6.25^{\mathrm{Bb}}$ & 0.22 & $*$ \\
$\mathrm{pH}$ & $6.13^{\mathrm{a}}$ & $6.29^{\mathrm{b}}$ & $6.17^{\mathrm{a}}$ & $6.19^{\mathrm{a}}$ & 0.16 & $\mathrm{~ns}$ \\
$\mathrm{WHC} \%$ & $64.60^{\mathrm{B}}$ & $71.30^{\mathrm{A}}$ & $63.80^{\mathrm{BDb}}$ & $65.60^{\mathrm{BCa}}$ & 0.91 & $*$ \\
$\mathrm{CL}, \%$ & $26.30^{\mathrm{AC}}$ & $22.50^{\mathrm{BD}}$ & $27.50^{\mathrm{A}}$ & $26.10^{\mathrm{BC}}$ & 0.24 & $*$ \\
$\mathrm{SF}\left(\mathrm{N} / \mathrm{m}^{2}\right)$ & $39.10^{\mathrm{AC}}$ & $34.50^{\mathrm{Bb}}$ & $37.50^{\mathrm{ADa}}$ & $36.80^{\mathrm{BC}}$ & 0.31 & $*$ \\
\hline
\end{tabular}

The data are average values of 6 tests: $\bar{X} \pm S E M, \quad A, B, C, D$ Values with different letters at the same line are significantly different at $P \leq 0.01$, a,b Values with different letters at the same line are significantly different at $P \leq 0.05, \quad \mathrm{~ns}=\mathrm{not}$ significant, ${ }^{*} P \leq 0.05,{ }^{*} P \leq 0.01$, THP: total heam pigments content, WHC: water holding capacity, CL: cooking loss, SF: shear force, SE: sensory evaluation, CU: conventional unit (red-pink intensity)

Table 8

Colour $\left(L^{*}, a^{*}, b^{*}\right)$ differences $(\Delta E)$ between individual flocks

\begin{tabular}{lllll}
\hline Flock & P66 & K2 & SB & P8 \\
\hline P66 & - & 5.33 & 2.95 & 0.25 \\
K2 & 5.33 & - & 6.09 & 5.48 \\
SB & 2.95 & 6.09 & - & 1.45 \\
P8 & 0.25 & 5.48 & 1.45 & - \\
\hline
\end{tabular}

The total haem pigments' content in analysed muscles depended on ducks' origin, too (Table 7). The differences between values of THP ranged from $2.55 \mathrm{mg} / \mathrm{g}-\mathrm{SB}$ up to $3.96 \mathrm{mg} / \mathrm{g}-\mathrm{K} 2$ and were statistically significant. The P66, P8, and SB leg muscles belong to a group with THP level comprised between 2.55 and $2.89 \mathrm{mg} / \mathrm{g}$ and the $\mathrm{K} 2$ had the highest THP content $(3.96 \mathrm{mg} / \mathrm{g})$. The results obtained for $L^{*}, a^{*}$ and $b^{*}$ parameters were in agreement with data established for the total haem pigment content. The muscles with the highest content of haem pigments (K2) were characterized by the lowest value in $L^{*}$ and $b^{*}$ parameters and the highest intensity of redness.

The colour of all investigated muscles was defined by the sensory panel as pink-red, with intensity in interval from 6.16 to $7.50 \mathrm{CU}$ (Table 7). The leg muscles of K2 were characterized by the highest intensity of red- pink colour, however the differences between P66, P8 and SB were not significant. These results of sensory evaluation were similar to those obtained for colour parameters, and THP content. Generally, the K2 muscles were the most distinct 
from remaining flocks in $L^{*}, a^{*}, b^{*}$, THP and SE parameters. No significant differences were observed in $\mathrm{pH}_{24^{4}}, \mathrm{WHC}, \mathrm{CL}, \mathrm{SF}$ values for P66, P8 and SB muscles. However the K2 muscles were characterized by higher $\mathrm{pH}_{24}, \mathrm{WHC}$ and lower $\mathrm{CL}$ and $\mathrm{SF}$ values (Table 7), it proves that they had the best analysed functional properties.

\section{Discussion}

Higher contents of lipids (1.9-6\%) was found in leg muscles of different Pekin type and their crossbreds (Knust 1995, Leskanich \& Noble 1997, Mazanowski \& Książkiewicz 2004, Chartrin et al. 2005) in comparison with our results. In the previous investigation we stated for Pekin type conservative flocks P33 and A3 similar content of lipids (1.73, 1.85\% respectively) in leg muscles (Wołoszyn et al. 2007). The protein content in the investigated muscles was higher than that determined by Mazanowski \& Książkiewicz (2004) for meat type ducks from two sire strains A44, A55 (18.6-18.8\%) and by Górska \& Górski (1997) for three and four-breed crosses of Pekin ducks (19.4\%). In comparison with our results obtained for conservative flocks, considerably lower cholesterol content was reported for Pekin $(68.5 \mathrm{mg} / 100 \mathrm{~g})$ and force fed Mulard (74.1 mg/100g) (Honikel \& Arneth 1996, Wołoszyn 2002). In previous work we observed a similar content of cholesterol in leg muscles of $A 3(117 \mathrm{mg} / 100 \mathrm{~g})$ and P33 (112 mg/100g) ducks (Wołoszyn et al. 2007). The profile of essential amino acid for the investigated leg muscles protein was similar to that obtained for P33 and A3 ducks (Wołoszyn et al. 2005). The coefficients of R for MET+CYS and LYS were characterized by a higher value than the other essential amino acids and it was in agreement with results obtained for Mulard and the conservative Pekin type A33 and A3 ducks (Wołoszyn 2002, Wołoszyn et al. 2005).

According to our findings with regard to the fatty acids composition it was stated that the UFA were predominant as for Muscovy, Pekin and Mulard ducks (Wołoszyn 2002, Chartrin et al. 2003). The UFA and the MUFA contents in fat of all investigated muscles were lower than those published by Chartrin et al. (2003) for Muscovy (64.6, 45.5\%), Hinny (66.5, 47.7\%), Mulard (67.2, 48.4\%) and Pekin (71.2, 54.7\%) ducks. These genotypes contained more PUFA than Muscovy (18.1\%), Hinny ( $18.8 \%)$, Mulard (18.7\%) and Pekin (16.5\%) and less SFA than Muscovy (36.4\%) ducks. The profile of fatty acids was similar to A3 Pekin type leg muscles. However, in spite of the same environmental conditions, the leg muscles of all investigated strains contained more UFA ( $\approx 6.1-8.02 \%)$ and less SFA ( $\approx 1.5-4.5 \%)$ than P33 flock (Wołoszyn et al. 2005). The higher UFA $(\approx 1.5-4.8 \%)$ and MUFA $(\approx 14.5-24.5 \%)$ content was observed in lipids of force fed Mulard ducks (Wołoszyn 2002) in comparison to our results. Leskanich \& Noble (1997) reported more SFA and less UFA in fat of muscles of commercial Pekin ducks. The PUFA:SFA and the $n-6: n-3$ PUFA ratios were significantly more favourable for investigated muscles than results obtained for Pekin, Muscovy, force fed Mulard (Wołoszyn 2002, Chartrin et al. 2003, 2005) and similar to $\mathrm{A} 3$ and P33 ducks (Wołoszyn et al. 2005). However, comparing all investigated parameters it should be mentioned that Pekin and Muscovy originate from two species genetically very distinct from each other. Moreover the diet composition used in the studies, the housing condition and age of the ducks were not the same, what can lead to the differences.

The data obtained by Skrabka-Błotnicka et al. (2002) for male leg muscles of Muscovy ducks were similar in $\mathrm{L}^{*}, \mathrm{a}^{*} \mathrm{~b}^{*}$ and THP values to results for $\mathrm{K} 2$ muscles. The results presented by Wołoszyn (2002) for Mulard (force fed) leg muscles were similar in $L^{*}, b^{*}$ and THP and higher 
in $a^{*}$ (21.30) than for P66, SB, and P8 flocks. The Mulard leg muscles were characterized by higher differentiation in the colour parameters, too. The colour parameters $L^{*}, a^{*}$ and $b^{*}$ stated by Skrabka-Błotnicka et al. (2003) for leg muscles of P33 and A3 Pekin type were comparable to the examined P66, SB and P8 flocks.

The total haem pigment content in leg muscles was similar to data established by Pikul et al. $(1982,1987)$ and Niewiarowicz et al. (1986) for different kinds of Pekin $(2.97-3.63 \mathrm{mg} / \mathrm{g})$. The values of $\mathrm{L}^{*}, \mathrm{a}^{*}, \mathrm{~b}^{*}, \Delta \mathrm{E}$ parameters as well as $\mathrm{THP}, \mathrm{pH}_{24}, \mathrm{WHC}, \mathrm{CL}$, SF were in the same range of those presented in the literature for the duck muscles. The slight differences between our results and other investigations were caused by different genotype of animals (Pikul et al. 1982, 1987, Niewiarowicz et al. 1986, Knust 1995, Işguar et al. 2002, Wołoszyn 2002, Chartrin et al. 2003, 2005), their age, sex, feeding, housing condition (Pingel 1988, Pingel \& Knust 1993, Baéza et al. 1999, Skrabka-Błotnicka et al. 2002, Kisiel \& Książkiewicz 2004, Wawro et al. 2004) and slaughtering condition (Chen et al. 1991, Romboli 1995). Moreover the methods of measurements or equipment used in the studies are not always the same, which can explain different values.

Taking into consideration the analysed functional traits of the leg muscles they can be divided into two groups: 1st group - K2 and 2nd - P66, P8 and SB. The K2 duck seems to have distinct muscle characteristics than the other ones. The body weight of $\mathrm{K} 2$ was the lowest (it represented Miniducks type) and it is the result of a crossbreed between Mallard and Pekin ducks, where P66, P8 and SB genotype is only Pekin. According to Kisiel \& Książkiewicz (2004), the K2 $\mathrm{m}$. biceps femoris was characterized by significantly lower diameters of aW (white) and $\beta R$ (red) fibres than Pekin type P33 flock. Biesiada-Drzazga et al. (2000) based on microstructural analysis of the $m$. biceps femoris found in A44 pedigree ducks greater diameter of the $a W$ and $\beta R$ fibres than those shown by Kisiel \& Książkiewicz (2004) for K2 ducks. Probably the fibre typology - more red fibres in K2 (Książkiewicz 1982) and the fibre size are not the same, and $\mathrm{K} 2$ breed finally varied in values for colour parameters, THP content, $\mathrm{pH}_{24^{\prime}}, \mathrm{WHC}, \mathrm{CL}$ and SF.

Comparing the basic chemical, amino acid composition, cholesterol content and profile of fatty acids, it could be concluded, that the P66 leg muscles coming from a selected breeding strain, are the most favourable from the nutritional point of view. It is evident too, that muscles from all the examined flocks have been characterized by a high nutritional value. In spite of the same feeding, housing condition and age the differences in chemical composition of leg muscles coming from examined ducks were observed. Probably different physiological mechanisms in the investigated ducks resulted in the differences in chemical composition.

Taking into consideration the functional properties, it was concluded that the muscles from investigated flocks varied in colour and analysed traits. The ducks of K2 are completely different in all functional properties. The advantages of K2 in comparing to P8, SB and P66 ducks are: darker colour typical of waterfowl meat, lower cooking loss, higher water holding capacity, lower shear force. The lower value of shear force can show that their meat is characterized by more suitable tenderness. For the consumers, disadvantage of the K2 ducks can be a relatively small body weight.

In the future the studies on the sensory evaluation of roasted meat are recommended as this is the most popular and required kind of product by consumers. 


\section{References}

AOAC Official Methods Analysis (1990) 15th ed. Association of Official Analytical Chemists, Washington DC, USA

Baéza E, Salichon MR, Marche G, Wacrenier N, Dominguez B, Culioli J (1999) Age and sex effects on the technological and chemical characteristics of mule duck meat. Proc. 1st World Waterfowl Conf, University of Taiwan, Taiwan, 531-537

Baéza E (2005) Major trends in research into domestic ducks and recent results concerning meat quality. Proc. XVII European Symposium on the Quality of Poultry Meat, 23-26 May, Doorwerth, The Netherlands, CDROM

Baryłko-Pikielna N, Matuszewska I (2009) Sensory investigation of food. Basis - Methods - Applications. Wydawnictwo Naukowe PTTŻ, Warszawa, Poland, 187-192 [in Polish]

Baryłko M (2000) Digital system and Software, CARET, Gdańsk, Poland 2000 [in Polish]

Biesiada-Drzazga, B, Górski J, Witak B (2000) Effects of feeding and age on thickness of muscle fibre in meat ducks of the A44 breed. Proc. XXI World's Poultry Congress, 20-24 August, Montreal, Canada, CD-ROM

Chartrin P, Mourot J, Bernadet M, Guy M, Duclos GJ, Baéza E (2003) Effect of genotype and force-feeding on the intramuscular fat deposition in duck. Proc. XVI European Symposium on the Quality of Poultry Meat, 23-26 September, Ploufragan, France, 224-230

Chartrin P, Schiavone A, Bernadet MD, Guy G, Mourot J, Duclos MJ, Baéza E (2005) Effect of genotype and overfeeding on lipid deposition in myofibres and intramuscular adipocytes of breast and thigh muscles of ducks. Reprod Nutr Dev 45, 87-99

Chen MT, Lin SS, Lin LC (1991) Effect of stresses before slaughter on changes to the physiological, biochemical and physical characteristics of the duck muscle. Br Poult Sci 32, 997-1004

Commission International de l'Eclairage (CIE) (1986) Colorimetry. Publication CIE 15.2, 2nd ed., Vienna, Austria

Folch J, Less M, Sloane J, Stanley GH (1957) A simple method for the isolation and purification of total lipids from animal tissues. J Biol Chem 226, 497-509

Górska A, Górski J (1997) The change of the total protein, collagen and fat content in Pekin duckcrossbreds at the end of rearing period. Proc. 13th Europ Symp on the Quality of Poultry Meat, Poznań, Poland, 334-337

Grau R, Hamm R (1957) Water holding capacity of mammal muscles. Z Lebensm Unters Forsch A 105, 446-460 [in German]

Haraf G, Książkiewicz J, Wołoszyn J, Okruszek A (2009) Characteristic of meat colour of different duck populations. Arch Tierz 52, 527-537

Honikel KO, Arneth W (1996) Cholesterol in meat and eggs. Fleischwirtsch 12, 1244-1253, 1329 [in German]

Işguar E, Kocak C, Pingel H (2002) Growth, carcass traits and meat quality of different local ducks and Turkish Pekins. Arch Tierz 45, 413-418

Kisiel T, Książkiewicz J (2004) Comparison of physical and qualitative traits of meat of two Polish conservative flocks of ducks. Arch Tierz 47, 367-375

Kotter L, Prandl O, Terplan G (1968) Determination of cooking loss in meat. Fleischwirtsch 14, 984 [in German]

Knust U (1995) Studies to characterize the effect of pre- and post mortem factors on carcass composition, muscle fiber composition and quality of ducks meat. Diss, Universität Halle [in German]

Książkiewicz J (1982) Miniduck. Biul Inf COBRD Poznań 21, 23-30 [in Polish]

Książkiewicz J (2002) Reproductive and meat characteristics of Polish ducks threatened with extinction. Czech J Anim Sci 47, 401-410

Książkiewicz J (2003) Comparison of reproduction and carcass traits in light type of ducks of four conservative flocks over eight generations. Arch Tierz 46, 377-389

Książkiewicz J (2007) Ducks. In: Instytut Zootechniki Balice/Kraków, Poland (ed.) Polish genetic resources, 8894 [in Polish] 
Leskanich CO, Noble RC (1997) Manipulation of the $n-3$ polyunsaturated fatty acid composition of avian eggs and meat. World's Poult Sci J 53, 155-183

Mazanowski A, Książkiewicz J (2004) Comprehensive evaluation of meat traits of ducks from two sire strains. J Anim Feed Sci 13, 173-182

Mazanowski A (2002) Breeding strains of ducks and their crossbreeds. In: Instytut Zootechniki Balice/Kraków, Poland (ed.) B-2, 3-25 [in Polish]

Ministry of Agriculture and Rural Development (2009) Dz. U. No. 63, item 589, 23 August (Journal of Laws, Directive concerning additional information placed on labels on animal feedstuff) [in Polish]

Niewiarowicz A, Pikul J, Czajka P (1986) Content of myoglobin and hemoglobin content in different types of poultry meat. Fleischwirtsch 66, 1281-1282 [in German]

Pikul J, Niewiarowicz A, Pospieszna H (1982) Content of haem pigment content in different types of poultry meat. Fleischwirtsch 62, 900-905 [in German]

Pikul J, Doruchowski W, Tański S, Reksiński T (1987) Slaughter yield, carcass composition, chemical analysis and technological properties of Muscovy and Pekin ducks. Biul Inf COBRD Poznań 4, 73-92 [in Polish]

Pingel H (1988) Ducks. VEB Deutscher Landwirtschaftverlag, Berlin, Germany, 89-127 [in German]

Pingel H, Knust U (1993) Review on duck meat quality. Proc. 11th Europ Symp on the Quality of Poultry Meat, Tours, France, 26-33

Rhee KS, Dutson TR, Smith GC, Hostetler RL, Reiser R (1982) Cholesterol content of raw and cooked beef Longissimus Muscles with different degrees of marbling. J Food Sci 47, 716-719

Romboli I (1995) Production factors and Meat Quality in Waterfowl. Proc. 10th Europ Symp on Waterfowl, Halle/Saale, Germany, 310-320

Skrabka-Błotnicka T, Orkusz A, Wołoszyn J (2002) The characteristic of the breast and leg muscles colour from Muscovy ducks. Proc. 45th Intern Congr Meat Sci and Technol, Rome, Italy, 538-539

Skrabka-Błotnicka T, Książkiewicz J, Orkusz A, Wołoszyn J, Kisiel T (2003) Evaluation of normal, PSE- and DFDlike condition in drakes' muscles from three Polish flocks. Proc. 16th Europ Symp on the Quality of Poultry Meat, Saint-Brieuc-Ploufragan, France, 112-116

Wawro K, Wilkiewicz-Wawro E, Kleczek K, Brzozowski W (2004) Slaughter value and meat quality of Muscovy ducks, Pekin ducks and their crossbreeds, and evaluation of the heterosis effect. Arch Tierz 47, 287-299

Wołoszyn J (2002) The physicochemical and technological characteristics of muscles from force-fed ducks. Dissertation, Wyd. AE Wrocław, 145 [in Polish]

Wołoszyn J, Książkiewicz J, Orkusz A, Skrabka-Błotnicka T, Biernat J, Kisiel T (2005) Evaluation of chemical composition of duck's muscles from three conservative flocks. Arch Geflügelk 69, 273-280

Wołoszyn J, Książkiewicz J, Skrabka- Błotnicka T, Haraf G, Biernat J, Kisiel T (2006) Comparison of amino acid and fatty acid composition of duck breast muscles from five flocks. Arch Tierz 49, 194-204

Wołoszyn J, Książkiewicz J, Skrabka-Błotnicka T, Haraf G, Biernat J, Szukalski G (2007) Chemical composition of leg muscles of six ducks strains. Med Weter 63, 658-661

Wołoszyn J, Haraf G, Książkiewicz J, Okruszek A (2009) Influence of genotype on duck meat colour. Med Weter $65,836-839$

Received 31 March 2011, accepted 23 June 2011.

Corresponding author:

Janina Wołoszyn

email: janina.woloszyn@ue.wroc.pl

Department of Animal Food Technology, Wrocław University of Economics, Komandorska 118/120, 53-345 Wrocław, Poland 